August 2021

\title{
Competing through coopetition: A strategy for success in hotel marketing consortia
}

\author{
Sofia Almeida \\ Universidade Europeia, Portugal, salmeida@universidadeeuropeia.pt \\ Ana Cláudia Campos \\ Universidade Europeia, Portugal, ana.campos@universidadeeuropeia.pt \\ Carlos Costa \\ University of Aveiro, Portugal, ccosta@ua.pt \\ José Manuel Simões \\ Universidade Lisbon, Portugal, jmsimoes@igot.ulisboa.pt
}

Follow this and additional works at: https://digitalcommons.usf.edu/jometr

Part of the Hospitality Administration and Management Commons, and the Marketing Commons

\section{Recommended Citation}

Almeida, S., Campos, A. C., Costa, C., \& Simões, J. M. (2021). Competing through coopetition: A strategy for success in hotel marketing consortia. Journal of Mediterranean Tourism Research, 1(1), 39-52.

https://www.doi.org/10.5038/2770-7555.1.1.1004

\section{Corresponding Author}

Sofia Almeida, Faculty of Tourism and Hospitality, Universidade Europeia, Rua Laura Ayres, nº4, Lote 17 1600-510

Lisboa, Portugal

Revisions

Submission date: April 16, 2021; 1st Revision: April 27, 2021; Acceptance: August. 20, 2021 


\title{
Competing Through Coopetition: A Strategy for Success in Hotel Marketing Consortia
}

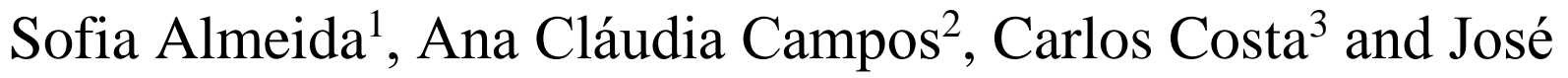 Manuel Simões ${ }^{4}$}

\author{
Faculty of Tourism and Hospitality \\ Universidade Europeia, Portugal and Ceg-Territur \\ Universidade Lisboa, Portugal \\ ${ }^{1}$ salmeida@universidadeeuropeia.pt \\ 2 ana.campos@universidadeeuropeia.pt \\ 4 jmsimoes@igot.ulisboa.pt \\ Universidade de Aveiro, Portugal \\ ${ }^{3}$ ccosta@ua.pt
}

\begin{abstract}
Coopetition is a strategy for a company to achieve a competitive advantage in the market environment. However, little is known about how coopetition works in the hotel sector and which organizational departments perform better in terms of coopetitive behaviour. In this research, coopetition is analysed in the context of international hotel marketing consortia (HMC) operating in Portugal. Exploratory interviews and a survey were conducted to consortia members to analyze managers' perceptions on coopetitive behaviour and the organizational departments engaged in coopetition. The results show that there is higher cooperation than competition in the marketing and research \& investigation departments. The research findings support consortia managers to make an informed decision to augment or reduce coopetition inside and outside companies based on two dimensions: internal and external. Internally by enhancing cooperation and reducing competition behaviour according to relationships observed between members; externally, by formulating strategies for the future, thereby increasing the intensity of coopetition according to expansion goals. Finally, theoretical and managerial contributions are presented, followed by recommendations for further research.
\end{abstract}

Keywords: coopetition, cooperation, competition, hotel marketing consortium, hotel sector

\section{Introduction}

Coopetition was first discussed by Brandenburguer and Nalebuff (1996), referring to a market situation in which two or more organizations cooperate and compete simultaneously. Prior research emphasizes coopetition as a strategy to achieve a firm's competitive advantage and its sustainable development (Della Corte \& Aria, 2016). The findings in the literature show that it materializes in different forms of alliances (Doz \& Hamel, 1998) and networks (Bengtsson \& Kock, 2000; Gnyawali \& Madhaven, 2001; Gomes-Casseres, 1994; Grängsjö \& Gummesson, 2005). Coopetitive behaviour is evident in the hotel sector (Almeida \& Guerreiro, 2012; Titmas, 2012), however, the research on coopetition dynamics is still scarce (Chim-Miki \& Batista-Canino, 
2017; Luo, 2007), in particular with a focus on analysis and measurement of coexistence of cooperative and competitive behaviours in networks.

Given the scarcity of the research on coopetition in the hotel sector, the question addressed in this research is to which extent are HMC informed by a coopetitive orientation, assuming HMC differ in their internal dynamics. Coopetition is here discussed from a business management perspective focused on the hotel sector, characterized by a lack of consistency in theory and conceptualization. Accordingly, the research objectives are: i) to analyse the cooperation and competition dynamics in the HMC operating in Portugal; ii) to identify the consortia departments, which perform better in terms of coopetitive behaviour; iii) to explore if the HMC departments closest to the end customer outperform the others in coopetitive behaviour.

The structure of this paper is as follows: firstly, a literature review is conducted on coopetition, drawing from key management and organizational research insights to the hotel sector. Then, the section of methods will describe main procedures followed the data collection methods, exploratory interviews and a questionnaire applied to seven international HMCs operating in Portugal. The last section of this paper will cover main findings and discussion, addressing also its limitations, as well as theoretical and managerial recommendations and suggestions.

\section{Literature Review}

\section{Cooperation}

Astley and Fombrun (1983, p.578) refer to cooperation relations as a collective strategy: "the joint mobilization of resources and formulation of action within collections of organisations". On the other hand, Mitchell and Singh (1996, p.170) describe cooperation as “(...) cooperative agreements between legally separable organizations that do not involve establishing separate organisations". With a voluntary perspective, Das and Teng (2000) define strategic alliances as voluntary cooperative inter-firm agreements for the purpose of achieving competitive advantage for parties involved. Others, such as Doz and Hamel (1998); Jorde and Teece (1989) emphasize the role of cooperation and trust in alliances. In each of the definitions mentioned above, emphasis is placed on how joint action between companies allows them to compete, reducing uncertainty, through increasing interdependence. Beresecká and Papcunová (2020) studied the cooperation applied to public-private partnerships in tourism in the Slovak Republic, focusing on the combination of knowledge, involving the share of risks, costs and benefits. Networks are a perfect business model to a society in constant transformation and allow individuals and organisations to be in a relational structure and interact with other actors. Thao, von Arx and Frölicher (2020) conducted a research on cooperation in transportation and tourism companies. Interfirm cooperation allows firms to acquire access to resources, thus helping them to overcome resource constraints and to achieve their own objectives more fully (Das \& Teng 2000).

\section{Competition}

The competition paradigm has dominated strategic management (Barney, 1986; Porter, 1986), organizational economics (Williamson, 1989), and marketing management (Drucker, 1996; Kotler, 1996). Brandenburger and Nalebuff (1996, p.7) claim that "the goal is to do well for yourself. Sometimes that comes at the expense of others, sometimes not. In business, your success 
doesn't require others to fail - there can be multiple winners". Regarding horizontal interdependence, the competitive perspective emphasizes the search for profit, either through the acquisition of a favourable position for the company (Porter, 1986) or through the mobilization and implementation of the company's distinct resources and competences that allow offering superior quality products when compared to competitors. Some examples of the competition paradigm could be found in the tourism sector. According to Gajdošik and Šmardová (2016), creation of competitive products in urban destinations requires the cooperation of stakeholders in the development of tourism. A climate of competition stimulates improvement and discourages stagnation, although efficiency and effectiveness of resources deployment create competitive advantage, as referred by Ritchie and Crouch (2003). Vodeb (2012) added that competition between destinations plays a critical role in shaping the global tourism industry. Patsouratis, Frangouli, and Anastasopoulos (2005) research on tourism competition among the Mediterranean destinations, which could be a good example for this. Although sun and sea tourism destinations are still popular, demand is decreasing, consequently competition among Mediterranean countries increases as destinations try to keep their sharing quota in the market.

\section{Conceptualizing Coopetition}

Coopetition was first discussed by Brandenburger and Nalebuff (1996), defining a market situation in which two or more organizations cooperate and compete simultaneously. Coopetition allows superior advantage for firms, which could not be achieved if engaging separately in cooperation and competition behaviours. The term is now widely accepted among the academic community, although the literature about the topic is mainly conceptual and dispersed (Chim-Miki \& BatistaCanino, 2017; Loebecke et al., 1999).

Bengtsson and Kock (2000, p. 412) define coopetition as "a dyadic and paradoxical relationship that arises when two companies are cooperating in some activities, while competing with each other in other activities". Luo (2004) suggests that global success of companies in an environment of high uncertainty and dramatic change requires the simultaneous adoption of competition and cooperation strategies. However, a coopetition behaviour does not arise simply from the combination of competition with cooperation, but instead from the creation of a new form of strategic interdependence between companies which gives rise to a coopetitive value system (Dagnino \& Padula, 2002).

Most studies on competition propose a conceptual framework (Dagnino \& Padula, 2002; Lado et al., 1997) and discuss empirical evidence as well (Bouncken et al., 2015; Gnyawali et al., 2008). Some researches focus on specific facets of coopetition. Walley (2007) examined coopetition in different economic periods and types of coopetition (internal-external). Other studies examined coopetition through the relationships developed between companies that compete in the same market and target the same consumer segments (Bengtsson \& Kock, 2000; Dagnino \& Padula, 2002). Bonel and Rocco (2007) identified different types of coopetition and discussed levels of analysis in types of coopetition, despite literature treating competition and cooperation as two extremes of one dimension (Gnyawali \& Madhavan, 2001).

Brandenburger and Nalebuff (1996), Lado et al. (1997) and Gnyawali and Madhavan (2001) highlight the growing importance of coopetition in the market dynamics and argue that the research has so far concentrated on conceptualization. Specifically, the previous research on coopetition 
strategies examined its determinants, instances and impacts on company performance (Yami et al., 2010). Thus, the implementation of strategies and management of coopetition are less studied topics (Walley, 2007), despite their critical role to the success of involved companies (Gnyawali et al., 2008). The early conceptualization of coopetition goes back to the Game Theory of Von Neumann and Morgenstern in 1944 (Bonel \& Rocco, 2007). Currently, the topic faces challenges rooted in the dynamics of environmental changes, which require companies to elaborate strategic thinking and action.

\section{Coopetition Applied to Business Management and Organization}

Coopetition as approached by Brandenburger and Nalebuff (1996) broke away from the mainstream literature, usually focused on firm strategic management and competitive position in the market. The new focus is now based on value creation and competitive advantages (Hill et al., 1990), as the most stable markets eventually become hypercompetitive, aggressively competitive, or in the stage for voracious competition (Yami et al., 2010).

The early studies on coopetition were conducted in the context of manufacturing industry. The lack of robust knowledge in service industries has been acknowledged (Dagnino \& Rocco, 2009; Drupe \& Grün, 2004; Huggins \& Izushi, 2007; Ritala \& Välimäki, 2009). One exception to this was Lusch, Vargo and O'Brien's research (2007). Cooperation is based on trust and reciprocity, while competition rests on the assumption that individuals act to maximize their own interests (Bengtsson \& Kock 2000; Bonel \& Rocco, 2007; Eriksson, 2008). Companies, usually seen as competitors, increasingly cooperate to achieve a competitive advantage in a globalized, less differentiated world. By working together, companies increase customer service and create a larger market at a lower cost than any other company working exclusively on its own.

More recently, Bounken et al. (2015) refer to shared costs, mitigated risks, shared economies of scale gained through investment activities. Companies involved proactively share their activities in the cooperation in upstream research (R\&D) area (Walley, 2007) and have access to knowledge and external resources, which can then apply to the company (Bengtsson \& Kock, 2000), increasing the efficiency of involved companies, generating win-win results with lower global costs. As a result of coopetition, partners develop a common knowledge base, using the experience and expertise of both companies (Ritala \& Välimäki, 2009), which increases innovation capacity (Bonnel \& Rocco, 2007; Quintana-Garcia \& Benavides-Velasco, 2004).

\section{Coopetition Strategy Applied to the Hotel Marketing Consortia}

HMC are networks of hotels, whose members share an umbrella brand, as well as resources (Almeida \& Campos, 2020). According to Kotler et al. (1996, p. 460), a HMC is "a group of hospitality organization that is allied for the mutual benefit for the members". Marketing is often the reason why consortia are formed (Ivanova \& Ivanov, 2015). Jafari (2000, p.104) defined a consortium as "an organization of individual trading units which combine for a common commercial purpose such as joint marketing services and purchasing”.

Prior research on hotel management explores cooperation practices (Astley \& Fombrun, 1983; Dyer \& Singh, 1998; Porter, 1986) or competition strategies (Ferrier, 2001; Porter \& Fuller, 1986; Zairi, 1996), but not how they do both simultaneously, within a coopetition mind-set. Coopetition 
in networks has been analysed among districts or regions (Dei Ottati, 1994), industries (Mariani, 2007), consortia (Carayannis \& Alexander, 2004), interest groups (Doucet, 2006), or networks of firms (Chaudhri \& Samson, 2000; Ims \& Jakobsen, 2006).

As a network, consortia develop a spirit of coopetition, i.e., members practice cooperative behaviours when they come together to promote the brand of a consortium or a common tourist destination, but they also compete, by developing mechanisms to obtain more reserves. Apparently, consortia are competing within networks and, thus, the type of relationship is to be an alliance between competitors. Consortia cooperate through the common promotion of services. Consortia compete, since they are opponents struggling among them to attract two target audiences, the hotel members (Business-to-business) relationship and the end-consumer (Business-to-consumer) relationship.

In tourism, firms compete locally whilst cooperating at the destination level to outperform other destinations (Pesämaa \& Hair, 2008). Advantages of coopetitive relationships are recognized in the sharing of industry-based information (Belleflamme \& Neysen, 2006), as well as in collective marketing communication with the purpose of promoting a destination (Grängsjö \& Gummesson, 2005). Titmas (2012) researched coopetition among the luxury hotels in Cape Town, concluding that both external (market environment) and internal (organizational) factors affect performance of coopetitive behaviour. Additionally, Titmas (2012) also found that certain activities are more likely to result in cooperation than others and that impacts are seen in increase revenues, occupancies, brand equity and cost. Sharing knowledge, resources, cost saving, maximising revenue, customer retention, improved product quality, improved service and highly skilled staff are observed as the elements of a successful coopetition strategy.

\section{Methods}

A mix-methods approach was applied in this research. This popular classification was introduced in 1989 by Greene et al. identifying five purposes for using mix-methods research: triangulation, complementary, development, initiation, and expansion. Triangulation was adopted in this study, looking for convergence, correspondence, and corroboration of results. The effectiveness of mixing methods is that qualitative and quantitative approaches are complementary rather than competitive methods (Decrop, 1999; Wilson, 1981). Accordingly, data collection methods included in this study were exploratory qualitative interviews, which were conducted in combination with literature review in the first stage of the research, so as to assist in the design of the survey. Additionally, these interviews intended to explore understanding and interpretation of technical concepts and meaning of the research themes. Subsequently, in the second stage, a survey was developed to address the research objectives. As for data analysis, exploratory interviews were content analysed according to the previously defined themes described below. The survey data were analysed by using SPSS software.

\section{Measurement of Coopetition}

The measurement of coopetition deserves some well-studied references in the literature. According to Walley (2007), coopetitive relations vary, each having its own idiosyncrasies. Afuah (2000), Hamel et al., (1990) analysed micro-coopetition, i.e., between departments or divisions within a company in North America, Europe and Japan. Later, Walley (2007) researched the existence of 
internal coopetition (interdepartmental, departments cooperate in certain areas and compete in others) and external coopetition (among consumers, for example, e.g., "Black Friday"). Measuring internal coopetition, Walley (2007) found that employees often cooperate in upstream activities and compete more in downstream activities, as shown in Figure 1 below. R\&D activities is well documented in Luo (2007) explains the emergence of coopetition and discusses situations in the business environment that promote increased cooperation and coopetition, presenting a model to understand the intensity and diversity of coopetition between rival companies.

Figure 1: Cooperation and Competition at the Organizational Department Level

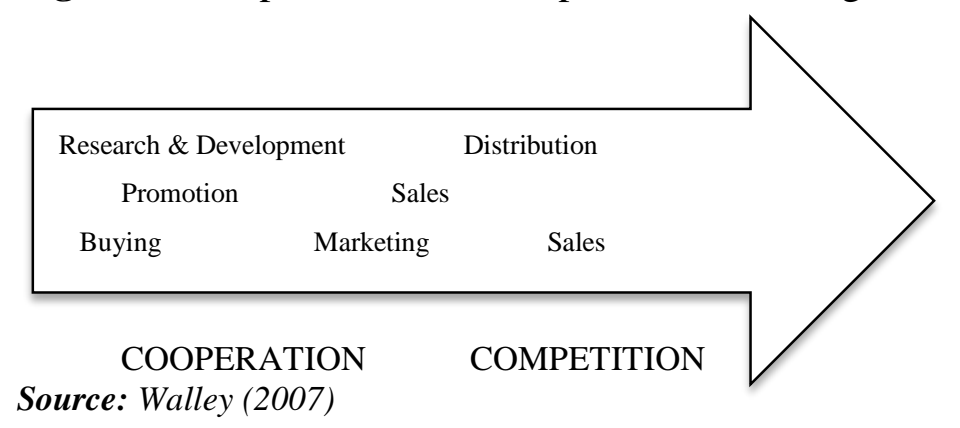

Sample

This study was conducted on two samples. The first one was composed of seven international HMC operating in Portugal, as seen in Table 1 below. Criteria for inclusion in the analysis were: (i) number of members operating in Portugal, (ii) consortia referenced in the literature in the last seven years, and (iii) consortia listed in the top 25 consortia worldwide (Hotelmag, 2020).

Table 1: Characterization of Hotel Marketing Consortia

\begin{tabular}{lcccc}
\hline Item & Headquarters & Country & $\begin{array}{c}\text { International } \\
\text { Presence }\end{array}$ & Members \\
\hline $\begin{array}{l}\text { ARTEH } \\
\text { http://www.arteh-hotels.com }\end{array}$ & Portugal & Lisbon, 2000 & 12 & 137 \\
$\begin{array}{l}\text { Design } \\
\text { https://www.designhotels.com }\end{array}$ & Germany & USA & 56 & 288 \\
$\begin{array}{l}\text { Great Hotels of the World (GHOW) } \\
\text { https://www.ghotw.com }\end{array}$ & Portugal & London & 23 & 285 \\
$\begin{array}{l}\text { Leading Hotels of the World (LHW) } \\
\text { https://www.lhw.com }\end{array}$ & Egypt & 2004 & 80 & 430 \\
$\begin{array}{l}\text { Preferred Hotels } \\
\text { https://preferredhotels.com }\end{array}$ & USA, Chicago & 1928 & 85 & 750 \\
$\begin{array}{l}\text { Relaís \& Chateaux } \\
\text { https://www.relaischateaux.com }\end{array}$ & France & Urance, & 61 & 549 \\
Small Luxury Hotels (SLH) & & 1954 & \\
https://slh.com & England & England & 90 & 520 \\
\hline
\end{tabular}

Source: Adopted from Ayazlar (2016); Holverson (2010); Holverson and Revaz (2006); Hotelmag (2020); Roper (1995).

The second sample was composed of 57 hotels taken from a population of 6884 and 5-star hotels operating in Portugal and the members of the above identified consortia. A survey was sent to 688 hotels and a total of 327 was validated. These 327 hotels are part of the seven consortia presented in Table 1 above. 


\section{Data Collection}

\section{Exploratory Interviews}

In order to prepare and design the survey, this study's key constructs were discussed with the experts in tourism. The exploratory interviews were conducted to a group of experts in the areas of sales, marketing and hotel management, using a script based on the following themes (Bengtsson \& Kock, 2000; Walley, 2007): (i) definition of HMC; (ii) mention to national and international HMC; (iii) reasons behind the emergence of HMC and critical success factors; (iv) advantages and disadvantages of being part of an HMC; (v) HMC operations; (vi) evidence of cooperation and (vii) competition inside these networks. The interviews allowed validation of the questionnaire design and wording, and implementation lasted for two months. The participants were the members of ARTEH - hotels and resorts consortia. The average duration of interviews was one and a half hour. The following procedures were observed to subsequent data treatment and analysis: i) interviews were recorded with the consent of interviewees; ii) eight open questions were asked to interviewees to assess sensitivity and level of knowledge about the subject to be discussed; iii) the interviews were subsequently transcribed and content analysed. The criteria adopted to select the hotel units to participate in these exploratory interviews were size (number of rooms) of a hotel, geographic location, target market segments and affiliation with hotel HMC. A questionnaire was afterwards designed and sent to hotel managers aiming at exploring their perceptions on coopetition within these international HMC. The questionnaire application lasted for four months, from March until June.

\section{Survey Structure and Measurement of Constructs}

The questionnaire was designed from the literature review (Bengtsson \& Kock, 2000; Walley, 2007) and from the results of the exploratory interviews. The first section of the survey addressed to the respondents' profiles. The second section focused on cooperation and competition in seven HMC departments. The first question was about the level of cooperation intensity and the second question was about the level of competition in consortium departments (marketing, research \& investigation; distribution; purchase; sales; service provision and production activities) (Bengtsson \& Kock, 2000; Walley, 2007). To measure coopetition, a scale was created based on the work of Walley (2007). For the purpose of this research, the consortia were divided in seven departments, upstream departments (production, purchasing and research \& development), and downstream departments (distribution, service provision, sales and production and marketing department) (Walley, 2007). A scale from 0 to 100 was used to measure the existence of cooperation and competition activities within the company departments.

\section{Data Analysis}

As argued by Babbie (1992), qualitative content analysis is increasingly being applied in management studies (Hsieh \& Shannon, 2005). Accordingly, the interviews were analysed using the predefined categories of the analysis. In turn, the data obtained from the questionnaire were analysed using a box of whiskers to measure the intensity of cooperation and competition. Quartiles are location measures that allow each variable to be accurately measured (White et al., 2015). The set of sample values between the $1^{\text {st }}$ and $3^{\text {rd }}$ quartiles is represented by a rectangle (box) with the median indicated by a bar. Next, two lines are considered that join the mediatrix on the 
sides of this rectangle with the so-called adjacent values. An adjacent lower AI value is defined as the lowest sample value (possibly the minimum), which is greater than or equal to Q1-1.5* (Q3Q1). Adjacent value superior to AS is defined as being the largest value of the sample (possibly the maximum), which is less than or equal to Q3 + 1.5* (Q3-Q1). Afterwards, a t-test for paired samples was run to compare the means of the variables for the same group.

\section{Findings}

The first statistical sample, the $7 \mathrm{HMC}$ are mainly located in Europe (Germany, France, the United Kingdom, and Portugal) and two in the USA (New York and Chicago). Only two consortia were created after the year 2000. The main services provided to the members are targeted marketing programs, joint branding advertising, sales support, social media campaigns, public relations and press office, international promotion (fairs and sales calls), advice on quality and technological solutions, marketing and branding and reservation centres.

The second statistical sample consists of 57 hotel units operating in Portugal, the majority classified as being 5 stars. The district with the largest population is Lisbon, followed by Faro district. Hotels are mostly urban and, according to more than $50 \%$ of the respondents were belonged to the luxury segment as the targeted customers. Most hotels were small-sized (less than 100 rooms) and employed between 21 and 60 employees.

The interviews provided useful insights regarding events organized by the HMC, which, according to the participants, show potential to build coopetition but achieve poor results, due to mismatch between target segments and travel agencies, concierge companies and tour operators' profiles. The interviewees also discussed the issues raised in the process of member selection, especially the one related to reputation. Often, new members did not fulfil the pre-requisites of service excellence demanded by the HMC. The participants complained about the lack of training programs for employees.

Considering cooperation vs. competition results, the data show that there is more cooperation than competition in the marketing and research \& development departments in the consortia, as shown in Figure 2.

Figure 2: Cooperation and Competition Behaviour in Departments of Marketing and R\&D
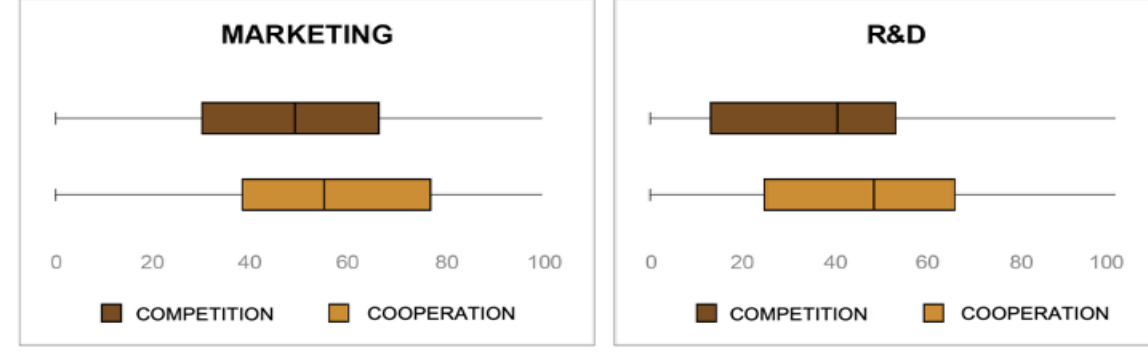

However, no statistically significant differences were found in the other departments as shown on Table 2. 
Table 2: Differences Between Cooperation and Competition Perceptions According to Different Departments in a Consortium

\begin{tabular}{|c|c|c|c|}
\hline Item & M (DP) & $\mathbf{T}$ & $\mathbf{P}$ \\
\hline Marketing $(\mathrm{n}=53)$ Cooperation & $57,60(23,326)$ & & \\
\hline Competition & $47,02(25,903)$ & 2,543 & ,014 \\
\hline I\&D $(n=52)$ Cooperation & $47,63(27,577)$ & & \\
\hline Competition & $37,44(26,417)$ & 2,358 & ,022 \\
\hline Distribution $(\mathrm{n}=53)$ Cooperation & $50,49(29,168)$ & & \\
\hline Competition & $47,38(28,360)$ &, 850 & ,399 \\
\hline Purchase $(n=39)$ Cooperation & $22,62(25,784)$ & & \\
\hline Competition & $21,41(24,060)$ & ,422 & ,675 \\
\hline Sales $(n=50)$ Cooperation & $51,94(30,883)$ & & \\
\hline Competition & $51,94(31,864)$ & ,000 &, 000 \\
\hline Service to client $(n=48)$ Cooperation & $56,29(31,595)$ & & \\
\hline Competition & $55,25(32,359)$ &, 252 &, 802 \\
\hline Production $(n=44)$ Cooperation & $43,36(30,666)$ & & \\
\hline Competition & $46,70(32,785)$ &,- 749 & ,458 \\
\hline
\end{tabular}

\section{Discussion and Conclusions}

Cooperative relationships characterize the marketing and research and development departments of the seven consortia analysed. This result corroborates Bengtsonn and Kock's (2000) results on cooperation between competitors. Concerning the existence of cooperation in other departments of the network, these results are in line with Jesus and Franco (2006). In the analysed HMC, cooperation is found in Marketing and R\&D departments. In the networks analysed by Jesus and Franco (2006) there is awareness of the need to develop interaction and cooperation in all areas in order to develop synergies among customers and build networks competitive advantage. Jesus and Franco (2006) recommended hotel and rural establishments involved in hospitality cooperation networks to develop cooperative behaviours to face competition, as it is easier to achieve business objectives as a group rather than in isolation. Thao et al., (2020) results show that public transportation companies generally cooperate more strictly with their homonymous companies than with their suppliers, due to their common client database and the strong political representation. In this research, the same conclusions were reached, as there was a strong perception of cooperation in the marketing and communication departments.

Walley (2007) argues that there is more competition activity in downstream activities (sales, distribution, and service) than in upstream activities (R\&D, purchasing and production). However, the statistical analysis conducted in this research allows no conclusion as to whether there is more cooperation and competition in the remaining departments. Marketing is between upstream and downstream activities, as it provides contributions to both directions, by facilitating cooperation in product and service promotion, and competing in distribution and sales. The direction of the arrow highlights activities that require greater exposure to and contact with stakeholders. Gajdošík, Šmardová (2016) identified motives for stakeholders to cooperate, specifically in the marketing area, namely coherent marketing communication, brand building and image and uniform reservation system. Barriers to cooperation were also identified, in terms of non-identification with the image of the target site and a misuse of marketing for one-sided benefit. 
The R\&D department is linked to innovation and demands human and financial resources and, thus, employees and companies come together to share resources and get better and faster results. The purchasing department is also a cooperating area, benefitting from economies of scale brought by negotiation of best prices, lower costs, and access to top quality raw materials from suppliers. The third upstream department is the production department, which benefits from the agreement between the parties to produce the best products and services. Applied to the tourism sector, the production of a package tour is the responsibility of tour operators and, implies sharing resources and expertise of the various items that comprise it (e.g., accommodation, airline, tourist attractions, rent-a-car).

Sales is a conflict and highly competitive zone, as a company aspires to outperform competitors. Internally, the Sales department is very competitive due to employee rivalry and dispute over commissions and success fees. Thao et al., (2020) show that cooperation is more intense with brokers in the sales departments, especially useful in keeping partners together, once that involves partnership agreements and a long-term investment. This is not in line with this research's results. The hotel members did not identify cooperation or competition at sales departments. Kylanen and Mariani (2012), and Rusko (2011) show a stronger spirit of cooperation in the R\&D department (back office), preventing collusion and theft of intellectual property from happening. In a perspective of pure cooperation, joint R\&D allows sharing resources and increasing innovation capacity through creation of new products and services. Once again, this research's results are noted in line with other findings due that no statistical differences in the sales department were observed. The distribution department is related to the competitive relationships between suppliers, since all parties aim at negotiating the best conditions and payment terms. Finally, provision of services is also a highly competitive department, as it is the sensitive area which requires interaction with clients, ability to attract new ones, as well as competence in retaining the existing ones.

Thus, this research's results partially corroborate Walley's (2007) findings, as a higher degree of cooperative behaviour was found in the R\&D department, and the Marketing department was identified as simultaneously cooperative and competitive.

This research discussed the existence of coopetition in the HMC internal departments according to the managers' perspectives. Coopetition is recognized as a business strategy potentially benefitting firms involved in a coopetitive relationship, thereby increasing the sector's overall competitiveness. Still, little is known about how coopetition works and performs in the hotel sector. This research was conducted to fill this gap in the literature. Prior research has been revealing that $\mathrm{HMC}$ engage in internal coopetitive relationships, however that coopetition is stronger in upstream activities than in downstream activities. The theoretical contribution of this study lies on the innovative focus on managers' perceptions about coopetition within consortia, as well as on the analysis conducted to the internal dynamics, explored by the departments. The results could help hotel companies to use coopetition to add value and to develop competitive advantage (Della Corte \& Aria, 2016).

The tourism industry is fertile in coopetition dynamics (Chim-Miki \& Batista-Canino, 2017). Coopetition is discerned, e.g. in destination promotion activities or in the joint efforts in capturing the interest of international tour operators. Still, hotels compete against each other for the best deals and contracts with travel agents and operators. In HMC, the level of knowledge creation and 
sharing is high (Ivanova \& Ivanov, 2015) but competition is also seen in individual absorptive capacity and value creation for the customer. As effective networks, HMC increase value through the sharing of knowledge, technology, promotion and distribution tools. Additionally, competitiveness is built through continuous training and teamwork. Cost reduction and economies of scale are the benefits derived from coopetitive HMC. Other dimensions of value creation within HMC include mechanisms to monitor and analyse hotel performance by comparing occupancy rates and average prices per night, distribution channels, among other performance measures. So, hopefully these reflections and results will contribute the body of knowledge of coopetition in hotels.

Managerially, this research provides guidance to consortia CEOs in the strategic decision-making process. Specifically, according to decision makers there is no adequate and careful selection of tour operators and operators participating in annual events or quality data sharing. Therefore, a recommendation could be given to the managers that they should take advantage of consortia arrangements to build high quality 'get together' moments. Cooperative behaviours should be fostered, and cooperative objectives encouraged, so that number of members joining consortia and satisfaction of members increase, thereby augmenting the bargaining power of HMC and respective competitive position in the market. The management of cooperation and competition balance inside each department is crucial for the success of HMC (Bouncken et al., 2015; Roper, 1992). Thus, each department has different, sometimes conflicting, needs and goals. This management process addresses the need to stimulate cooperative behaviour while constraining competitive behaviour, based on collusion and opportunism.

Opportunities for new and pertinent research on this topic emerge from this research. Since no statistically significant differences were observed in HMC departments other than Marketing and $\mathrm{R} \& \mathrm{D}$, future research should explore and measure coopetition contextualized in service companies, specifically those related to tourism and hospitality. Moreover, as innovation is currently crucial to market competitiveness, more investigation is needed to examine the influence of cooperative and competitive behaviour of HMC on ability to innovate. Pursuing the studies similar to this one presented will expectedly help consortia to better approach the current, and highly dynamic, global market by adopting a coopetition framework.

\section{References}

Afuah, A. (2000). How much do your coopetitors' capabilities matter in the face of technological change?. Strategic Management Journal, 21(3), 397-404.

Almeida, S., \& Campos, A.C. (2020). Termos nas áreas disciplinares de Marketing. In: A. Correia, \& A. Rodrigues (Eds.), Turismo e Hospitalidade de A a Z (pp. 428). Edições Actual.

Almeida, S., \& Guerreiro, S. (2012). The coopetition as new trend in chains of hotels, In: N. Abranja (Eds.), Tourism training and innovation studies and experiments (pp. 544-555). Pedagogical Issues.

Astley, W. G., \& Fombrun, C. J. (1983). Collective strategy: Social ecology of organizational environments. Academy of Management Review, 8(4), 576-587.

Ayazlar, G. (2016). Entry modes: marketing consortium.. The Routledge handbook of hotel chain management. London: Routledge, 171-184.

Babbie, E. (1992). The practice of social research. Macmillan.

Barney, J.B. (1986). Types of competition and the theory of strategy: Toward an integrative framework. Academy of Management Review. 11(4), 791-800.

Belleflamme, P., \& Neysen, N. (2006). Coopetition in information: The ruraltrip.com case. Uclouvain. https://uclouvain.be/en/research-institutes/lourim/working-papers-2006.html 
Bengtsson, M., \& Kock, S. (2000). Coopetition in business Networks: To cooperate and compete simultaneously. Industrial Marketing Management, 29(5), 411-426.

Beresecká, J., \& Papcunová, V. (2020). Cooperation between municipalities and the private sector in the field of tourism. Scientific Papers of the University of Pardubice. Series D, Faculty of Economics \& Administration, 28(4), 1074-1079.

Bonel, E., \& Rocco, E. 2007. Coopeting to survive: Surviving coopetition. International Studies of Management and Organization, 37(2), 70-96.

Bouncken, R. B., Gast, J., Kraus, S., \& Bogers, M. (2015). Coopetition: A systematic review, synthesis, and future research directions. Review of Managerial Science, 9(3), 577-601.

Brandenburger, A. M., \& Nalebuff, B. J. (1996). Co-opetition: A revolution mindset that combines competition and cooperation: the game theory strategy that's changing the game of business. Doubleday.

Carayannis, E. G., \& Alexander, J. (2004). Strategy, structure, and performance issues of precompetitive R\&D consortia: insights and lessons learned from Sematech. IEEE Transactions on Engineering Management, 51(2), 226-232.

Chaudhri, V., \& Samson, D. (2000). Business-government relations in Australia: Cooperating through task forces. Academy of Management Perspectives, 14(3), 16-24.

Chim-Miki, A. F., \& Batista-Canino, R. M. (2017). Tourism coopetition: An introduction to the subject and a research agenda. International Business Review, 26(6), 1208-1217.

Dagnino, G. B., \& Padula, G. (2002, May 9-11). Coopetition strategic: Towards a new kind of interfirm dynamics. [Conference presentation]. EURAM - The European Academy of Management Second Annual Conference, Stockholm, Sweden. http://ecsocman.hse.ru/data/977/644/1219/coopetition.pdf

Dagnino, G. B., \& Rocco, E. (Ed.). (2009). Coopetition strategy: theory, experiments, and cases. Routledge.

Das, T. K., \& Teng, B. S. (2000). Instabilities of strategic alliances: An internal tension perspective. Organization Science, 11(1), 77-101.

Decrop, A. (1999). Triangulation in qualitative tourism research. Tourism Management, 20(1), 157-161.

Dei Ottati, G.D. (1994). Cooperation and competition in the industrial district as an organization model. European Planning Studies, 2(4), 463-483.

Della Corte, V., \& Aria, M. (2016). Coopetition and sustainable competitive advantage. The case of tourist destinations. Tourism Management, 54, 524-540.

Doucet, P. (2006). Territorial cohesion of tomorrow: A path to cooperation or competition?. European Planning Studies, 14(10), 1473-1485.

Drucker, P.F. (1996). The landmarks of tomorrow: A report on the new 'post-modern' world. NJ: Transaction.

Doz, Y. L., \& Hamel, G. (1998). Alliance advantage: The art of creating value through partnering. Harvard Business.

Drupe, K., \& Grün, T.W. (2004). The use of category management practices to obtain a sustainable competitive advantage in the fast-moving-consumer-goods industry. Journal of Business and Industrial Marketing, 19(7), 444-459.

Dyer, J. H., \& Singh, H. (1998). The relational view: Cooperative strategy and sources of interorganizational competitive advantage. Academy of Management Review, 23(4), 660-679.

Eriksson, P. E. (2008). Achieving suitable coopetition in buyer-supplier relationships: The case of AstraZeneca. Journal of Business-to-Business Marketing, 15(4), 425-454.

Ferrier, W. J. (2001). Navigating the competitive landscape: The drivers and consequences of competitive aggressiveness. Academy of Management Journal, 44(4), 858-877.

Gajdošik, T., \& Šmardová, L. (2016). Cooperation of Stakeholders in Urban Tourism Destinations. [Conference presentation]. 19th International Colloquium on Regional Sciences, Brno: Masarykova Univerzita, 984-999.

Gnyawali, R.D., \& Madhaven, R. (2001). Network structure and competitive dynamics: A strucural embeddedness perspective. Academy of Management Review, 26(3), 431-445.

Gnyawali, D. R., He, J. I., \& Madhavan, R. (2008). Co-opetition: Promises and challenges. In C. Wankel (Eds.), 21 st Century Management (pp.386-398). Sage.

Gomes-Casseres, B. (1994, July-August). Group versus group: How alliance networks compete. Harvard Business Review, 62-74. https://hbr.org/1994/07/group-versus-group-how-alliance-networks-compete

Grängsjö, Y., \& Gummesson, E. (2005). Hotel networks and social capital in destination marketing. International Journal of Service Industry Management, 17(1), 58-75.

Greene, J. C., Caracelli, V. J., \& Graham, W. F. (1989). Toward a conceptual framework for mixed-method evaluation designs. Educational Evaluation and Policy Analysis, 11(3), 255-274. 
Hamel, G., Doz, Y., \& Prahalad, C. (1990, January- February). Collaborate with your competitors. Harvard Business Review, 67(1), 133-139.

Hill, C. W., Hwang, P., \& Kim, W. C. (1990). An eclectic theory of the choice of international entry mode. Strategic Management Journal, 11(2), 117-128.

Holverson, S., \& Revaz, F. (2006). Perceptions of European independent hoteliers: Hard and soft branding choices. International Journal of Contemporary Hospitality Management, 18(5), 398-413.

Holverson S., Holverson K, Mungall A., \& Centeno A. (2010). The strategic importance of affiliations with lifestyle consortium for small (Rapport final, école hôteliere de Lausanne).

Hotelmag Magazine (2020) Hotels 325 Ranking. Marketingandtechnology. http://www.marketingandtechnology.com/repository/webFeatures/HOTELS/H2007_SpecialReport325.pdf

Huggins, R. A., \& Izushi, H. (2007). Competing for knowledge: creating, connecting and growing. Routledge.

Hsieh, H. F., \& Shannon, S. E. (2005). Three approaches to qualitative content analysis. Qualitative Health Research, 15(9), 1277-1288.

Ims, K. J., \& Jakobsen, O. D. (2006). Cooperation and competition in the context of organic and mechanic worldviews-a theoretical and case-based discussion. Journal of Business Ethics, 66(1), 19-32.

Ivanova, M., \& Ivanov, S. (2015). The nature of hotel chains: An integrative framework. International Journal of Hospitality \& Tourism Administration, 16(2), 122-142.

Jafari, J. (2000). Encyclopedia of tourism. Routledge.

Jesus, C., \& Franco, M. (2016). Cooperation networks in tourism: A study of hotels and rural tourism establishments in an inland region of Portugal. Journal of Hospitality and Tourism Management, 29, 165-175.

Jorde, T. M., \& Teece, D. J. (1989). Competition and cooperation: Striking the right balance. California Management Review, 31(3), 25-37.

Kylanen, M., \& Mariani, M. M. (2012). Unpacking the temporal dimension of coopetition in tourism destinations: Evidence from Finnish and Italian theme parks. Anatolia, 23(1), 61-74.

Kotler P., Bowen J., \& Makens J. (1996). Marketing for hospitality and tourism. Prentice Hall.

Lado, A. A., Boyd, N. G., \& Hanlon, S. C. (1997). Competition, cooperation, and the search for economic rents: A syncretic model. Academy of Management Review, 22(1), 110-141.

Loebecke, C., Fenema, P. C., \& Powell, P. (1999). Co-opetition and knowledge transfer. ACM SIGMIS Database, 30(2), 14-25.

Lusch, R. F., Vargo, S. L., \& O’Brien, M. (2007). Competing through service: Insights from service-dominant logic. Journal of Retailing, 83(1), 5-18.

Luo, Y. (2004). A coopetition perspective of MNC-host government relations. Journal of International Management, 10(4), 431-451.

Luo, Y. (2007). A coopetition perspective of global competition. Journal of World Business, 42(2), $129-144$.

Mariani, M.M. (2007). Coopetition as an emergent strategy: Empirical evidence from an Italian consortium of opera houses. International Studies of Management and Organisation, 37(2), 97-126.

Mitchell, W., \& Singh, K. (1996). Survival of businesses using collaborative relationships to commercialize complex goods. Strategic Management Journal, 17(3), 169-195.

Patsouratis, V., Frangouli, Z., \& Anastasopoulos, G. (2005). Competition in tourism among the Mediterranean countries. Applied Economics, 37(16), 1865-1870.

Pesämaa, O., \& Hair Jr, J. F. (2008). Cooperative strategies for improving the tourism industry in remote geographic regions: An addition to trust and commitment theory with one key mediating construct. Scandinavian Journal of Hospitality and Tourism, 8(1), 48-61.

Porter, M. (1986). Estratégia competitiva: Técnicas para análise de indústrias e da comcorrencia (Second Edition). Editora Campus. GEN Atlas.

Porter, M. E., \& M. B. Fuller (1986). Coalitions and global strategy. In M. E. Porter (Eds.), Competition in Global Industries (pp. 315-343). Harvard Business.

Quintana-Garcia, C., \& Benavides-Velasco, C. A. (2004). Cooperation, competition, and innovative capability: A panel data of European dedicated biotechnology firms. Technovation, 24(12), 927-938.

Ritchie, J.R.B., \& Crouch, G.I. (2003). The competitive destination. Cabi.

Ritala, P., \& Välimäki, K. (2009). Intrafirm coopetition, knowledge creation and innovativeness. In: B. G. Dagnino, \& E. Rocco (Eds.), Coopetition strategy (pp. 84-93). Routledge.

Roper, A. J. (1992). Hotel consortia: strategies and structure; an analysis of the emergence of hotel consortia as transorganisational forms [Doctoral dissertation, University of Huddersfield]. Queensgate. http://eprints.hud.ac.uk/id/eprint/4847/1/DX176743.pdf 
Rusko, R. (2011). Exploring the concept of coopetition: A typology for the strategic moves of the Finnish forest industry. Industrial Marketing Management, 40(2), 311-320.

Thao, V. T., von Arx, W., \& Frölicher, J. (2020). Swiss cooperation in the travel and tourism sector: long-term relationships and superior performance. Journal of Travel Research, 59(6), 1044-1060.

Titmas, K. (2012). Coopetition amongst hotels in South Africa: a case study of coopetition amongst five-star hotels in Cape Town, South Africa [Doctoral dissertation, Stellenbosch University]. Stellenbosch. http://citeseerx.ist.psu.edu/viewdoc/download?doi=10.1.1.916.6610\&rep=rep1\&type=pdf

Vodeb, K. (2012). Competition in tourism in terms of changing environment. Procedia-Social and Behavioural Sciences, 44, 273-278.

Walley, K. (2007). Coopetition: An introduction to the subject and an agenda for research. International Studies of Management \& Organization, 37(2), 11-31.

White, H., Kim, T. H., \& Manganelli, S. (2015). VAR for VaR: Measuring tail dependence using multivariate regression quantiles. Journal of Econometrics, 187(1), 169-188.

Wilson, T. (1981). Qualitative "versus" quantitative methods in social research. BMS: Bulletin of Sociological Methodology / Bulletin De Méthodologie Sociologique, 10, 25-51.

Williamson, O. E. (1989). Transaction cost economics. In R. Schmalensee, \& R. D. Willing (Eds.), Handbook of Industrial Organization (pp. 135-182). Berkeley.

Yami, S., Castaldo, S., Dagnino, B., \& Le Roy, F. (2010). Coopetition: Winning strategies for the 21st century. Edward Elgar.

Zairi, M. (1996). Effective benchmarking. Springer Science \& Business Media. 